https://doi.org/10.15407/scine16.04.050

\author{
KOLOMIETS, V.M., SHKURAT, O.I., KRAVCHENKO, S.M., \\ LOPATKIN, R.YU., CHYZHOV, I.G., SAMOILOV, P.E., \\ PAVLENKO, YU.A., MELNYK, M.O., and HONCHARENKO, O.I. \\ Institute of Applied Physics, the NAS of Ukraine, \\ 58 , Petropavlivska St., Sumy, 40030, Ukraine, \\ +380 542222794, +380 542223760 , ipfmail@ipfcentr.sumy.ua
}

\title{
VACUUM DEVICE FOR APPLYING COATINGS TO THE INNER SURFACE OF THE PIPES BY MAGNETRON SPUTTERING
}

Introduction. Due to the mechanical and chemical wear of the inner surfaces of the tubular products, there is a need to create protective coatings for these surfaces, which will increase the life of such products in various industries.

Problem Statement. When designing equipment to obtain high-quality protective coatings on the inner surface of pipes, there are some difficulties associated with space limitations. Plasma sputtering with cylindrical magnetrons is widely used in the world. However, the questions about improving the sputter equipment to increase its efficiency and to improve the physical and mechanical properties of the coatings are current interest. The need of manufacturing universal equipment for processing of different diameter pipe products of is also urgent.

Purpose. Development and creation of the test bench magnetron sputtering system for deposition coatings on the inner surfaces of pipe products with a diameter of $30 \mathrm{~mm}$ using the method of high-power impulse magnetron sputtering.

Materials and Methods. The design elements of the magnetron sputter are made of stainless steel with a roughness not greater than Ra 2.5. The method of high-power impulse magnetron sputtering (HIPIMS) was used in the experiments.

Results. The design documentation for the magnetron sputtering system has been developed. The stand for deposition of the protective coatings on the inner surface of pipe products with a diameter of $30 \mathrm{~mm}$ has been manufactured. Using created cylindrical magnetron sputtering system may be realized in one technological cycle as to ionic cleaning internal surface of tubes and as to deposition new coatings.

Conclusion. The prospects for creating the industrial equipment to solve the urgent problem of obtaining the quality coatings inside the pipes have been confirmed by positive results during the magnetron sputtering system prototype tests.

Keywords: magnetron sputtering system, HIPIMS method, an inner surface of the pipes, cylindrical magnetron, and magnetron sputter.

Citation: Kolomiets, V.M., Shkurat, O.I., Kravchenko, S.M., Lopatkin, R.Yu., Chyzhov, I.G., Samoilov, P.E., Pavlenko, Yu.A., Melnyk, M.O., and Honcharenko, O.I. Vacuum Device for Applying Coatings to the Inner Surface of the Pipes by Magnetron Sputtering. Sci.innov. 2020. V.16, no.4. P.50-56. https://doi.org/10.15407/ scine16.04.050 
The inner surfaces of tubular parts and elements of industrial equipment can be subject to significant mechanical and chemical wear, especially when operating in chemically aggressive environments. Obviously, such factors lead to decreasing service life, destruction, and corrosion of pipe products. Therefore, enhancing the mechanical, thermal and chemical stability of the surfaces of such parts is quite relevant today [1].

At the present stage of technology development, the most promising and common methods for modifying the inner surfaces of pipe products are plasma deposition of coatings [2 - 4]. Among these methods, the magnetron sputtering method plays an important role, since it enables obtaining high-quality coatings with improved physical, mechanical, and chemical properties and has a high reproducibility of technological process [5-7]. Improvement of this method has led to the emergence of its subtype, the so-called HIPIMS technique that uses high-power pulses, thereby increasing the ion density of sputtered substance in plasma. As a result, this leads to better adhesion and, accordingly, improved surface morphology of the coatings [8-10].

Because of the peculiarities of the shape of tubular parts there is a certain difficulty of access to their inner surfaces, which creates technical and technological difficulties in implementing effective magnetron sputtering systems for deposition of high-quality coatings on the inner surfaces of pipes. Leading research laboratories have started with creating cylindrical magnetron sputtering systems [11]. However, there are problems related to the creation of sputtering equipment that has a high efficiency and power, the improvement of the physical, mechanical, and chemical properties of the resulting films, and the development of consistently repetitive technologies.

To solve the problem of deposition of high-quality protective coatings on the inner surface of tubular products, the Institute of Applied Physics of the NAS of Ukraine (Sumy, Ukraine) has created a magnetron sputtering system (Fig. 1) consisting of 2 cylindrical magnetrons (CM) (Fig. 2) [12].

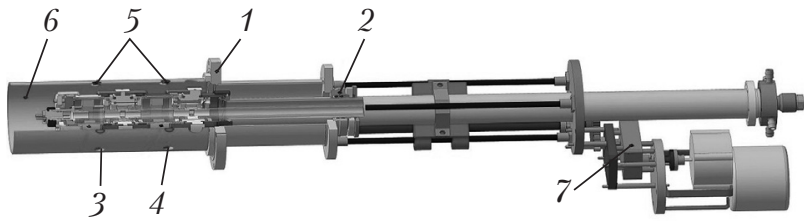

Fig. 1. Magnetron sputtering system with cylindrical magnetron: 1 - connecting flange; 2 - sealant; 3,4-magnetrons; 5 - substrates; 6 - fragment of the pipe; $7-$ mechanism for magnetrons displacement

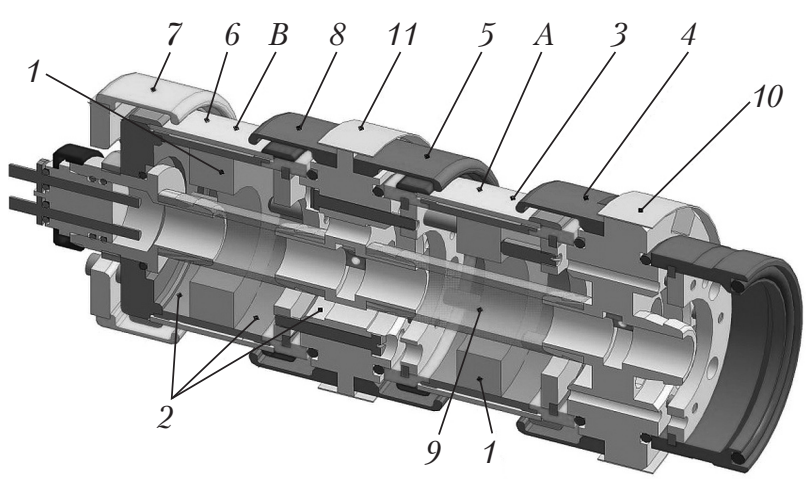

Fig. 2. Cross section of cylindrical magnetron prototype: $A-$ the first magnetron; $B$ - the second magnetron; 1 - magnets with $\mathrm{SmCo} ; 2,9--$ leak proof channels; 3, 6- target cathodes; 4, 5, 7, 8- anodes; 10, 11 - protective screens

The created cylindrical magnetron sputtering system has enabled carrying out both ionic cleaning of an internal surface of pipes and deposition of new coatings in one technological cycle. In addition, it is possible to work in one of the two modes: direct current or pulsed current. Another advantage of the created magnetron sputtering system is the ability to obtain multilayer coatings by increasing the number of CMs.

As a result of tests of a magnetron sputtering machine prototype, a coating of refractory and chemically stable materials with improved physical and mechanical properties has been obtained (as described in detail in [12]). Successful tests and available design documentation make it possible to create an industrial plant for deposition of protective coatings on tubular products for various applications.

The developed magnetron system with CM can be used only for tubular products with an inner diameter of, at least, $60 \mathrm{~mm}$. Continuing the 
development, the author's team has created design documentation and a magnetron sputtering system prototype based on the HIPIMS technique for deposition of coatings on the inner surfaces of tubular products with a diameter over $30 \mathrm{~mm}$.

\section{DESCRIPTION OF THE CONFIGURATION OF MAGNETRON SPUTTERING SYSTEM PROTOTYPE BASED ON THE HIPIMS TECHNIQUE}

The 3D model of the designed magnetron sputtering machine for deposition of protective coatings on the inner surfaces of pipes with a diameter over $30 \mathrm{~mm}$ is shown in Fig. 3.

The magnetron sputtering system consists of the following main elements:

1. Vacuum chamber that ensures the environment friendly realization of the technological process at a residual gas pressure of $10^{-4} \mathrm{~Pa}$. The chamber can be heated to a temperature of about $180^{\circ} \mathrm{C}$ by external heating elements;

2. Pipe simulator with a diameter of $30 \mathrm{~mm}$; its design enables varying samples without any additional costs;

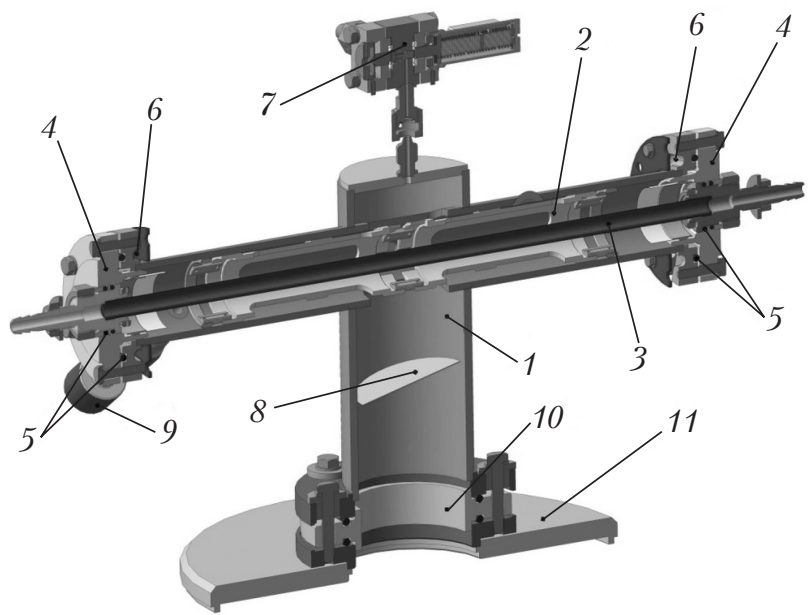

Fig. 3. 3D-model of a magnetron sputter for applying protective coatings: 1 - vacuum chamber; 2 - pipe simulator (diameter over $30 \mathrm{~mm}$ ); 3 - cathode; 4 - "cathode-vacuum chamber" flange insulators; 5 - rubber sealing rings; $6-$ water cooling channels; 7 - working gas (argon) supply valve; 8 - valve; 9 - vacuum sensor; 10 - insulator; 11 "vacuum chamber-testing device" flange

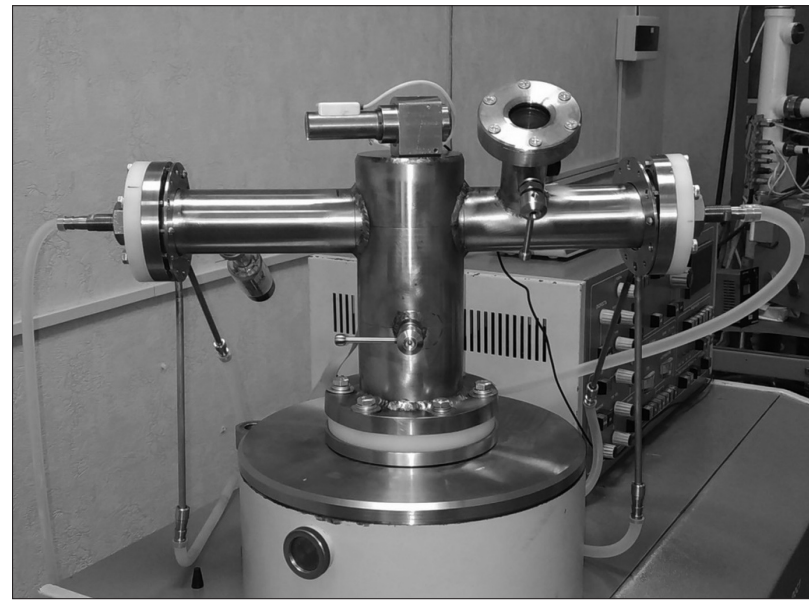

Fig. 4. Vacuum chamber with magnetron sputtering system

3. Cathode that is cooled by running distilled water;

4. Flanges that ensure the tightness of the connection between the cathode and the vacuum chamber, as well as their mutual electrical insulation;

5. Rubber rings that provide vacuum tightness of joints;

6. Channels for cooling the flange insulators by running water;

7. Leybold valve (Germany) that provides a dosed overflow of Ar into the chamber during the creation of the primary plasma;

8 . Valve that regulates the pumping-out rate during deposition;

9. Sensor for measuring the degree of rarefaction in the vacuum chamber;

10. Electrical insulator between the test device chamber and the vacuum system.

11. Flange for connecting the chamber of the stand with the vacuum system.

Fig. 4 shows the designed vacuum chamber with a magnetron sputtering system. All structural elements are made of stainless steel. Given the requirements for the inner surfaces of vacuum parts, these parts have a roughness parameter $\mathrm{Ra} \leq 2.5$. The welds are vacuum-tight; their quality is checked using a helium leak detector Varian 925-40. 
To test and operate the magnetron sputtering system, a power supply scheme and a vacuum circuit diagram have been developed, on the basis of which a device for testing the sputtering technological process has been designed and manufactured (Fig. 5).

All elements of the device for exercising the technological process of magnetron sputtering method meet requirements for vacuum hygiene and tightness and operate in an automatic mode according to the program set by operator. The device is equipped with necessary systems for water cooling of the structural elements, has an inlet for connecting the working gas and vacuum-tight electrical connectors that enable heating the samples to the required temperature and monitoring this process. The designed and manufactured sputtering system prototype has been fully adapted to operation with this system. Before starting the device operation and periodically while operating, the insulation resistance of structural elements is measured using a DT-6605-type insulation resistance meter at a test signal voltage of $2500 \mathrm{~V}$. The operating device may have a supply voltage of the magnetron up to $1200 \mathrm{~V}$.

The scheme of power supply of the magnetron sputtering system is shown in Fig. 6. The electrical circuit is based on the provision of two stable physical phenomena necessary for the operation of the magnetron: the creation of mutually perpendicular magnetic and electric fields between a pipe subject to sputtering and the cathode as a source for sputtering refractory metals.

For creating the magnetic field in the cylindrical magnetron, a FlexKraft 12V / 1200A rectifier unit (KraftPowercon Sweden AB, Sweden) with air cooling has been selected as a power source (Fig. 7). This power supply has a current or voltage stabilization mode and creates a current through the cathode (copper tube) up to $1200 \mathrm{~A}$, at a voltage at its ends up to $12 \mathrm{~V}$. While the current is flowing, perpendicular to the cathode axis, there appears a magnetic field with a magnetic induction up to $26 \mathrm{mT}$ (at a current of $1200 \mathrm{~A}$ ). It is sufficient to create a stable "trap" of electrons.

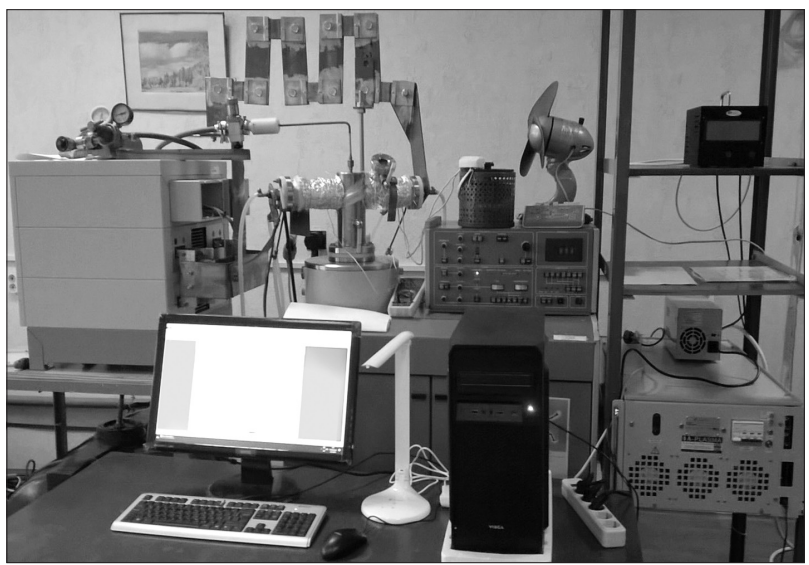

Fig. 5. Testing device for exercising the sputtering technological process

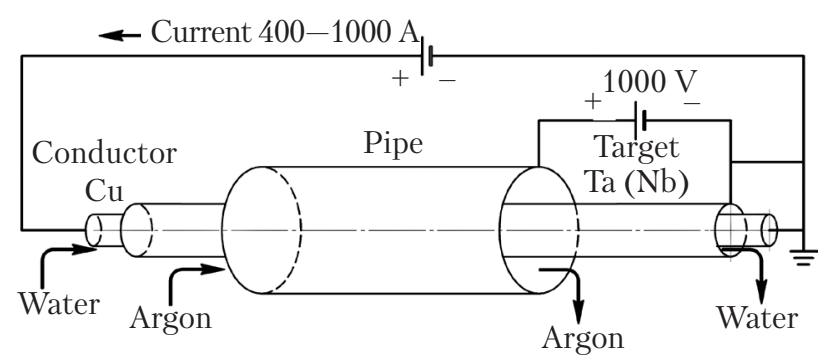

Fig. 6. Magnetron sputter electrical connection diagram

The fundamental difference between the HIPIMS technology and the classical magnetron sputtering method is a high discharge power density that may reach several $\mathrm{kW} / \mathrm{cm}^{2}$. This is 100 times higher than in the case of traditional magnetron sputtering in the direct current (DC) or the medium frequency (MF) modes. The plasma concentration near the target may be several orders of magnitude higher than the values typical for the direct current magnetron sputtering, which leads to an increase in the share of ions in the flux of sputtered material. The ionization of the target material may reach more than $50 \%$, with metal ions charged both +1 and +2 , while in the case of direct current magnetron sputtering, it does not exceed $15 \%$.

In order to create an electric field for the magnetron sputtering system prototype we use a 4A-PLASMA hip-V-6 kW power supply (Fig. 8). Using this module enables sputtering the coa- 


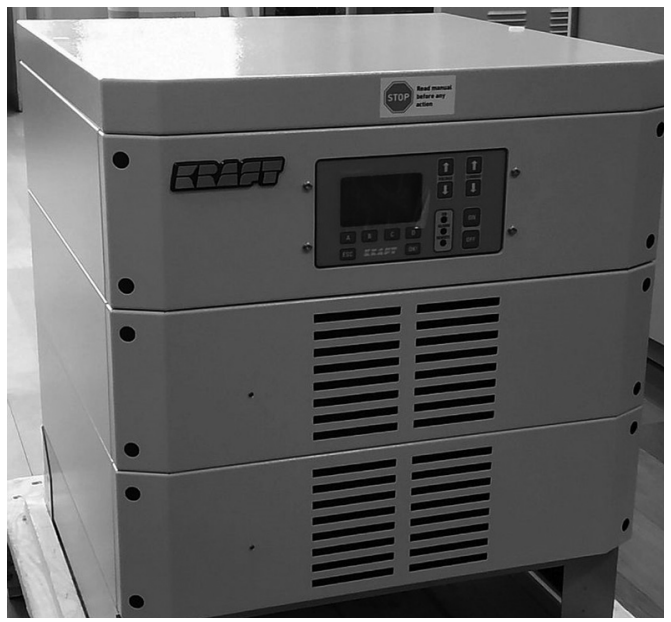

Fig. 7. Power supply source of FlexKraft $12 \mathrm{~V} / 1200$ A rectifier unit

tings both in the direct current and in the HIPIMS modes. The parameters of the magnetron power supply are given in Table below.

The 4A-PLASMA unit is equipped with software that can be connected to a personal computer and is completely controllable by it.

\section{Technical Specifications of 4A-PLASMA hip-V-6 kW Power Supply}

Wattage output, $\mathrm{kW} \ldots \ldots \ldots \ldots \ldots \ldots \ldots$

Output pulse power, $\mathrm{kW} \ldots \ldots \ldots \ldots \ldots \ldots . . \ldots 500$

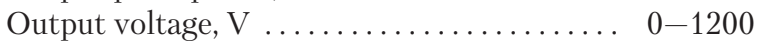

Output current, A .................. $\quad 0-500$

Frequency of output pulses, $\mathrm{kHz} \ldots \ldots \ldots \ldots . \quad 1$

Pulse duration, $\mu$ s .................. . 5-1000

Arc discharge response time, at most, $\mu \mathrm{s} . . . . \quad<3$

Protection from arc discharge current, A . . . . 50-1000

Voltage ripple, $\% \ldots \ldots \ldots \ldots \ldots \ldots \ldots \ldots$

Supply voltage, $V \ldots \ldots \ldots \ldots \ldots \ldots \ldots$. . . . . . 3 phases 380

Input current, A . . . . . . . . . . . . . . . $\quad<13$

Coolant ........................... Air

The main functions of the software are as follows:

1) to control the performance of the device in real time;

2) to change the parameters of the device in real time;

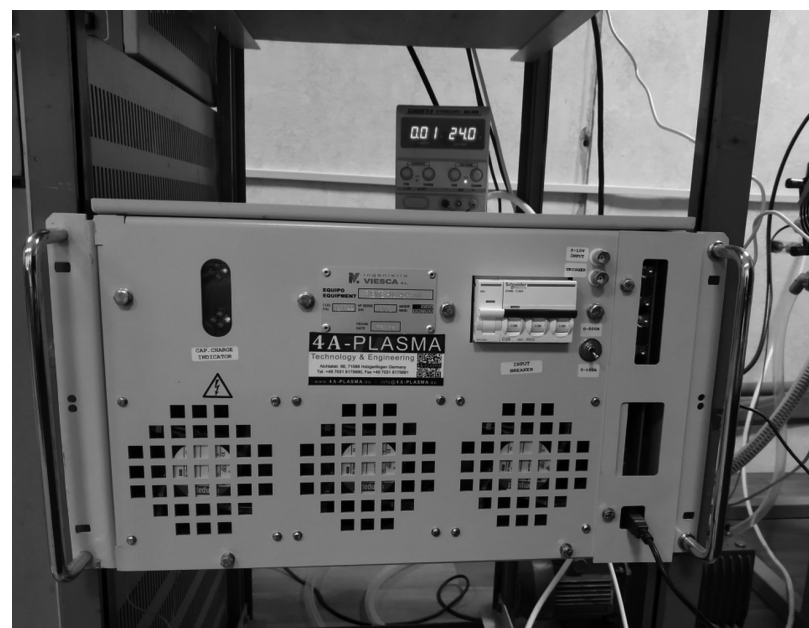

Fig. 8. 4A-PLASMA hip-V-6 kW power supply unit

3) to record the operation of the device and to autonomously reproduce the recorded session.

The personal computer is also used to monitor and to control the operation of the vacuum module, it is a center that collects data from all control devices and organizes feedback between them.

Hence, to solve the problem of deposition of highquality protective coatings on the inner surface of tubular products, the author's team has developed design documentation for magnetron sputtering system prototype that can be used for deposition of protective coatings on the inner surface of pipes with a diameter over $30 \mathrm{~mm}$.

Based on the developed documentation, a magnetron sputtering system prototype has been created and successfully tested using a specially designed and manufactured testing device. Test sputtering has been made in both DC and HIPIMS modes. The process of coatings deposition is controlled by a personal computer.

The successful tests of the magnetron sputtering system prototype have confirmed good prospects of creating industrial equipment for deposition of high-quality coatings on the inner surfaces of pipe products. 


\section{REFERENCES}

1. Krutikov, A. V., Devyatyarov, M. S. (2014, November). Increased service life, repair and restoration using thermal spraying technologies. Welding and diagnostics: a collection of reports of the international forum (25-27 November, Ekaterynburh). Ekaterynburh [in Russian].

2. Nadtoka, V. N., Pankov, R. V., Deyneko, L. N., Maslyanyy, N. V. (2009). Environmentally friendly coating method for internal surfaces. Artillery and Small Arms, 1, 54-57 [in Russian].

3. Perekrestov, V. I., Kravchenko, S. N., Kosminskaya, Yu. A., Kononenko, I. N. (2011). The structure of the Ni-Cu system condensates obtained by ion sputtering of composite rods. Metallophysics and the latest Technology, 2, 203-210 [in Russian].

4. Ananeva, E. A. (2007). Development of a technology for applying plasma heat-shielding coatings to small-sized internal complex profile surfaces of parts of a hot gas turbine engine. PhD (Tech.) Samara [in Russian].

5. Hasiy, O. B. (2018). Development of vacuum ion-plasma sputtering technology and directions of its improvement. Scientific Bulletin of NLTU of Ukraine, 10, 85-91 [in Ukrainian]. doi:10.15421/40281018

6. Bebenin, A. N., Rudyy, V. I., Litovchenko, V. N., Vorobev, R. A., Yankitova, I. A., Karnavskaya, T. G. (2014). Investigation of the mechanical properties of protective refractory coatings deposited by ion-plasma vacuum magnetron sputtering. Proceedings of the R.E. Alekseeva Nizhny Novgorod State Technical University, 5, 43-146 [in Russian].

7. Moskvitin, G. V., Birger, E. M., Polyakov, A. N., Polyakova, G. N. (2015). High technology hardening coatings. Metalworking, 1, 44-49 [in Russian].

8. Kouznetsov, V., Macak, K., Schneider, J. M., Helmersson, U., Petrov, I. (1999). A novel pulsed magnetron sputter technique utilizing very high target power densities. Surface and Coatings Technology, 2-3, 290-293.

9. Lepesh, G. V., Ivanova, E. S. (2016). Simulation of thermodynamic effects when testing the resistance of protective coatings. Technical and technological Problems of Service, 2, 7-17 [in Russian].

10. Alami, J., Eklund, P., Andersson, J. M., Lattemann, M., Wallin, E., Bohlmark, J., ..., Helmersson, U. (2007). Phase tailoring of Ta thin films by highly ionized pulsed magnetron sputtering. Thin Solid Films, 515, 3134-3438. doi:10.1016/j. tsf.2006.10.013

11. Yee, F., Wotzak, M., Cipollo, M. L., Traszkowska, K. (2004). Cylindrical magnetron sputtering in a ferromagnetic cylinder. Fall Newes Bulletin SVC, 28-34.

12. Shkurat, O. I., Baturin, V. A., Buhajov, S. I., Karpenko, O. Yu., Kravchenko, S. M., Kolomiets, V. M., ..., Danylenko, M. I. (2019). Development of technology for the process of processing the gun barrel channel to increase its life. Weapons and military equipment, 1 (21), 35-40 [in Ukrainian].

Received 10.01.20

Revised 28.02.20

Accepted 18.03.20

В.М. Коломієць, О.І. Шкурат, С.М. Кравченко, Р.Ю. Лопаткін,

І.Г. Чижов, П.Е. Самойлов, Ю.А. Павленко, М.О. Мельник, О.І. Гончаренко.

Інститут прикладної фізики НАН України,

вул. Петропавлівська, 58, Суми, 40030, Україна,

+380 54222 2794, +38054222 3760, ipfmail@ipfcentr.sumy.ua

\section{ВАКУУМНИЙ ПОСТ ДЛЯ НАНЕСЕННЯ ПОКРИТТІВ НА ВНУТРІШНЮ \\ ПОВЕРХНЮ ТРУБ МЕТОДОМ МАГНЕТРОННОГО РОЗПИЛЕННЯ}

Вступ. Внаслідок механічного та хімічного зносу внутрішніх поверхонь трубоподібних виробів існує необхідність створення захисних покриттів останніх, що збільшить ресурс їх використання в різних галузях промисловості.

Проблематика. При створенні обладнання для отримання якісних захисних покриттів внутрішньої поверхні труб виникають деякі труднощі, пов'язані з обмеженістю простору. В світовій практиці широко застосовують методи плазмового напилення з циліндричними магнетронами. Однак, актуальними залишаються питання удосконалення розпилювального обладнання для збільшення його ефективності та покращення фізико-механічних властивостей покриттів. Також нагальною потребою є виготовлення універсального обладнання для обробки трубних виробів різного діаметру.

Мета. Розробка й створення стенду з дослідним зразком магнетронної розпилювальної системи для напилення покриттів на внутрішні поверхні трубних виробів діаметром від 30 мм з використанням методики магнетронного розпилення імпульсами високої потужності. 
Матеріали й методи. Елементи конструкції магнетронного розпилювача виготовлено 3 нержавіючої сталі 3 параметром шорсткості $R a \leq 2,5$. В експериментах використано метод магнетронного розпилення імпульсами високої потужності (HIPIMS - High-pотеr impulse magnetron sputtering).

Результати. Розроблено конструкторську документацію на магнетронну розпилювальну систему та виготовлено стенд для напилення захисних покриттів на внутрішні поверхні трубних виробів діаметром від 30 мм. Використовуючи створену циліндричну магнетронну розпилювальну систему, можна здійснювати в одному технологічному циклі як іонне очищення внутрішньої поверхні труб, так і напилення нових покриттів.

Висновки. Позитивні результати з випробування дослідного зразка магнетронної розпилювальної системи показали перспективність створення промислового обладнання для вирішення актуальної проблеми отримання якісних покриттів внутрішньої поверхні труб.

Ключові слова: магнетронна розпилювальна система, метод HIPIMS, внутрішня поверхня труб, циліндричний магнетрон, магнетронний розпилювач. 